\title{
Effect of mifepristone in cervical ripening for induction of labour
}

\author{
Rutuja Athawale*, Neema Acharya, S. Samal, C. Hariharan
}

Department of Obstetrics \& Gynecology, Jawaharlal Nehru Medical College, AVBRH, Sawangi, Meghe, Wardha, Maharashtra-442002, India

Received: 6 December 2012

Accepted: 6 January 2013

*Correspondence:

Dr. Rutuja Athawale

E-mail: dr.rutuja.athawale@gmail.com

\begin{abstract}
Background: Mifepristone is potentially a method of inducing labour in late pregnancy by increasing uterine contractility and by increasing the sensitivity of the uterus to the actions of prostaglandins. Present study was done to portrait the beneficial of mifepristone induction of labour. The objective was to study the effect of mifepristone in induction of labour with the outcome of induction of labour (IOL).

Methods: 100 patients (term) were included, after their informed consent. Patients were categorized by BISHOP SCORE at the beginning of induction for comparison of BS, mode of delivery, induction delivery interval (IDI). Women undergoing induction with RU486 (200mg PO) were grouped in one and those with placebo control group into another. Statistical analysis of categorical variables was done.

Results: Rate of successful IOL or vaginal delivery was $76 \%$ in study group and only $36 \%$ in control group. After induction with mifepristone for cervical ripening in study group $76 \%$ patient who had cervical score $<3$ on admission had cervical score improved to $>8$ within 24 hours, whereas in control group $2 \%$ female's cervical score was $>8$. Among the babies, $44 \%$ in the control group required baby unit admission as compared to $36 \%$ in the study group.

Conclusions: In the present study, the women who were induced with mifepristone $200 \mathrm{mg}$ per orally showed drastic improvement in cervical score within 24-48 hours and decreased the cesarean rate in the study group and amount of dose requirement of augmentation of labour with Misoprostol or Oxytocin, lesser NICU admission and maternal complication.
\end{abstract}

Keywords: Mifepristone, Induction of labour, RU486.

\section{INTRODUCTION}

Induction of labour is carried out in over $20 \%$ of pregnancies on an average in developed countries. ${ }^{1}$ Indicated to be advantageous for both the mother \& baby. Decrease perinatal morbidity and mortality. ${ }^{2,3}$ Induction between 37-41 weeks has the potential to improve neonatal outcomes.

Methods of Induction of Labour: [A] Medical: Use of Mifepristone ${ }^{4}$, Prostaglandin, 5 ,6 Synthetic oxytocin preparations, natural induction, Relaxin. ${ }^{7}$ [B] Mechanical: "Membrane sweep“/"stretch and sweep", Artificial rupture of the membranes.
Indication for Induction of labour: Post-term pregnancy, Intrauterine fetal growth retardation, Medical disorders of pregnancy (e.g. she has pre-eclampsia), Premature rupture of the membranes, premature termination of the pregnancy (abortion), scheduling concerns, fetal death in uterus, twin pregnancy continuing beyond 38 weeks.

Mifepristone /RU-(486), a new class of pharmacological agents (antiprogestins) have been developed to antagonize the action of progesterone. Of these, mifepristone (also called RU 486) is best known. It is a 19 nor-steroid which has greater affinity for progesterone receptors than does progesterone itself. It blocks the action of progesterone at the cellular level. 
Pharmacokinetics of Mifepristone: It is characterized by rapid absorption, long half-life of 25 to 30 hours. $^{8}$ Key metabolites also has high affinity to progesterone receptors. Mifepristone is a potential as a method of inducing labour in late pregnancy through its actions in antagonizing progesterone, thus increasing uterine contractility and by increasing the sensitivity of the uterus to the actions of prostaglandins. ${ }^{9}$

\section{Aim and Objectives}

- To study the effectiveness and safety of mifepristone for cervical ripening for Induction of labour in term pregnancies.

- To compare the effect mifepristone in study group with a control group of same size.

- To observe the improvement in cervical score as compared to control group.

- To view the final outcome of the interventional group and compare it with the control group.

- To study the occurrence of neonatal complications in study and compare it to control group.

\section{METHODS}

A randomized case control study comparing effect of mifepristone for cervical ripening in labour induction, with placebo/no treatment. Place of study: Acharya Vinoba Bhave Rural Hospital, Sawangi (Meghe), Wardha.

Inclusion Criteria: Patient giving consent for the study, singleton pregnancy, cases included were of gestational at term after 37 completed weeks, they had normal latest sonography without any complications.

Exclusion Criteria: Patient not giving consent for the study, multiple pregnancies, any obstetric cause for contraindication for induction of labour (previous scar on uterus, any coagulation failure, placenta previa). Patients with any other associated medical condition or disease which contraindicates the use of mifepristone example: Adrenal insufficiency.

The patients in the study group received one tablet mifepristone $200 \mathrm{mg}$ per oral stat at induction into the trial. Then the patient was reviewed for bishop score after 24 hours and 48 hours. Any progression of associated conditions was also noted.
Subgroup analyses will be limited to the primary outcomes:

- Vaginal delivery achieved within 24-48 hours

- Requirement of augmentation

- Uterine hyper stimulation with fetal heart rate (FHR) changes

- Instrumental delivery or Caesarean section

Secondary outcomes:

- Cervix unfavourable/unchanged after 48 hours.

- Serious neonatal morbidity or perinatal death (e.g. seizures, birth asphyxia defined by trial lists, neonatal encephalopathy, disability in childhood).

- Serious maternal morbidity or mortality (e.g. uterine rupture, admission to intensive care unit, septicaemia).

\section{RESULTS}

Out 50 study group women (Total $n=100), 34$ (68\%) were primigravida and $16(32 \%)$ were multiparas, whereas out of 50 women in control group 26 (52\%) were primigravida and $24(48 \%)$ were multigravida. The patients were stratified by Bishop Score at entry for further analysis.

Table 1: Characteristics of study and control group.

\begin{tabular}{|c|c|c|c|}
\hline \multirow{2}{*}{ Characteristic } & \multicolumn{2}{|l|}{ Group } & \multirow{2}{*}{$p$ Value } \\
\hline & $\begin{array}{l}\text { Study } \\
\text { group }\end{array}$ & $\begin{array}{l}\text { Control } \\
\text { group }\end{array}$ & \\
\hline $\begin{array}{l}\text { Maternal age } \\
\text { in yr (Mean } \\
+/-2 \mathrm{SD})\end{array}$ & $\begin{array}{l}22.86 \pm \\
2.89 \mathrm{yrs}\end{array}$ & $\begin{array}{l}23.4 \pm \\
3.25 \mathrm{yrs}\end{array}$ & $\begin{array}{l}0.45, \mathrm{NS}, \\
p>0.05\end{array}$ \\
\hline Range & $19-30 \mathrm{yrs}$ & $19-35$ yrs & \\
\hline $\begin{array}{l}\text { Gestational } \\
\text { age (Mean +/- } \\
\text { 2SD) }\end{array}$ & $\begin{array}{l}39.29 \pm \\
0.90 \mathrm{wks}\end{array}$ & $\begin{array}{l}39.42 \pm \\
0.73 \mathrm{wks}\end{array}$ & $\begin{array}{l}0.42, \mathrm{NS}, \\
p>0.05\end{array}$ \\
\hline Range & $\begin{array}{l}37-41.3 \\
\text { wks }\end{array}$ & $38-41$ wks & \\
\hline
\end{tabular}

Table 2: Outcome of induction in study and control group.

\begin{tabular}{|c|c|c|c|c|}
\hline Outcome & Study & Control & $\aleph 2$-value & $p$ value \\
\hline Vaginal delivery & $38(76 \%)$ & $18(36 \%)$ & \multirow{2}{*}{32.47} & $p<0.0001$ \\
\hline LSCS & $12(24 \%)$ & $32(64 \%)$ & & Significant \\
\hline Augmentation required & $13(26 \%)$ & $40(80 \%)$ & 58.53 & $\begin{array}{l}p<0.0001 \\
\text { Significant }\end{array}$ \\
\hline
\end{tabular}


Table 3: Mode of delivery in relation to initial Bishop Score $\leq \mathbf{3}$ prior induction in study and control group.

\begin{tabular}{|llll|}
\hline Mode of delivery & Study & Control & $p$ value \\
\hline Vaginal & $38(76 \%)$ & $17(34 \%)$ & 17.82 \\
$p>0.0001$ \\
\hline LSCS & $12(24 \%)$ & $33(66 \%)$ & Not significant \\
\hline Total & $50(100 \%)$ & $50(100 \%)$ &
\end{tabular}

Table 4: Improvement in Bishop's Score with increase in induction duration time in study as compared to control.

\begin{tabular}{|c|c|c|c|c|}
\hline \multicolumn{5}{|c|}{ On admission } \\
\hline $\begin{array}{l}\text { Bishop } \\
\text { Score }\end{array}$ & Study & Control & «2-value & $p$-value \\
\hline$\leq \mathbf{3}$ & $42(84 \%)$ & $29(58 \%)$ & \multirow{2}{*}{8.20} & \multirow{2}{*}{$\begin{array}{l}0.004 \\
S, p<0.05\end{array}$} \\
\hline$>3$ & $8(16 \%)$ & $21(42 \%)$ & & \\
\hline \multicolumn{5}{|c|}{ After 24 hours } \\
\hline$\leq \mathbf{3}$ & $0(0 \%)$ & $2(4 \%)$ & \multirow{3}{*}{8.20} & \multirow{3}{*}{$\begin{array}{l}0.004 \\
\mathrm{~S}, p<0.05\end{array}$} \\
\hline 4-8 & $14(28 \%)$ & $43(86 \%)$ & & \\
\hline$>8$ & $36(72 \%)$ & $5(10 \%)$ & & \\
\hline
\end{tabular}

Table 5: APGAR Score and NICU admission in relation to study and control group.

\begin{tabular}{|c|c|c|c|c|}
\hline Apgar Score <7 & Study Group & Control Group & $x^{2}$-value & $p$-value \\
\hline 1 minute & $6(12 \%)$ & $15(30 \%)$ & \multirow{2}{*}{5.76} & \multirow{2}{*}{$\begin{array}{l}0.01 \mathrm{~S}, \\
p<0.05\end{array}$} \\
\hline 5 minute & $0(0 \%)$ & $8(16 \%)$ & & \\
\hline \multicolumn{5}{|c|}{ Admission to NICU } \\
\hline Yes & $18(36 \%)$ & $22(44 \%)$ & \multirow{3}{*}{1.44} & \multirow{3}{*}{$\begin{array}{l}0.24 \mathrm{NS}, \\
p>0.05\end{array}$} \\
\hline No & $32(64 \%)$ & $28(56 \%)$ & & \\
\hline Total & $50(100 \%)$ & $50(100 \%)$ & & \\
\hline
\end{tabular}

\section{Maternal complications in relation study and control group}

Cases of failed induction were omitted in calculation of complications. The majority did not have any major complications in either of the group like sepsis, pyrexia and PPH. Just few minor genital tract injuries but the difference was not significant statistically in the study group.

\section{DISCUSSION}

Hapangama D, Neilson JP (May 2009) ${ }^{9}$, in their study of "Mifepristone for induction of labour" compared to placebo (108 women), mifepristone treated women were more likely to have a favourable cervix at 48 hours [risk ratio (RR) $2.41,95 \%$ confidence intervals (CI) 1.70 to 3.42]. Effect persisted at 96 hours (RR 3.40, 95\% CI 1.96 to 5.92). Less need of augmentation with oxytocin (RR $0.80,95 \%$ CI 0.66 to 0.97$)$. Less likely to undergo caesarean section or failure of induction [RR $0.74,95 \%$
CI 0.60 to 0.92 ], [RR $0.40,95 \%$ CI 0.20 to 0.80 ]. More likely to have an instrumental delivery (RR $1.43,95 \%$ CI 1.04 to 1.96). A single dose of $200 \mathrm{mg}$ mifepristone appears to be the lowest effective dose for cervical ripening (RR 2.13, 95\% CI 1.15 to 3.97). Abnormal fetal heart rate patterns were not common (RR $1.85,95 \% \mathrm{CI}$ 1.17 to 2.93 ). The above mentioned points what we observed in our study also.

Li L, Gao W, Chen $\mathrm{S}^{5}$ did a study at Beijing Tian Tan Hospital, Capital University of Medicine on Labour induction in women at term with mifepristone and misoprostol. Results of their study women who were given mifepristone: the cervical length was $1-3 \mathrm{~cm}$ shorter and Bishop score was 4-5 higher than those before treatment. The cervical ripening ratio was $100.00 \%$. Incidence of the onset of labor was $93.00 \%$. Incidence of vaginally delivery was $80.88 \%$ after misoprostol was given for augmentation. Similarly in our study vaginal delivery rate was $76 \%$ and rate of augmentation was $26 \%$. 


\section{CONCLUSIONS}

The final conclusion after conducting this research is: Mifepristone, a progesterone antagonist, is known to cause softening and dilation of the human pregnant cervix and an increase in uterine activity. It is theoretically attractive for use as an adjunct in cervical priming and labour induction. Mifepristone is associated with an increase in the chance of vaginal delivery within 24-48 hours with decreasing incidence of LSCS. Hence mifepristone combined with or without augmentation is a safe, efficient, economical and convenient induction agent for initiation of labor in women at term. Therefore, this may justify future trials comparing mifepristone with the routine cervical ripening agents currently in use.

Funding: No funding sources

Competing interests: There are no competing interests to declare

Ethical approval: The study was approved by the Institutional ethics committee

\section{REFERENCES}

1. Mealing NM, Roberts CL, Ford JB, Simpson JM, Morris JM. Trends in induction of labour, 1998-2007: a population-based study. Aust N Z J Obstet Gynaecol 2009;49:599-605.
2. Gulmezoglu AM, Crowther CA, Middleton P. Induction of labour for improving birth outcomes for women at or beyond term. Cochrane Database Syst Rev 2006;4:CD004945.

3. Smith GC. Life-table analysis of the risk of perinatal death at term and post term in singleton pregnancies. Am J Obstet Gynecol 2001;184:489-96.

4. Clark K, Ji H, Feltovich H, Janowski J, Carroll C, Chien EK. Mifepristone-induced cervical ripening: structural, biomechanical, and molecular events. Am J Obstet Gynecol. 2006;194:1391-8.

5. Li L, Gao W, Chen S. Labour induction in women at term with mifepristone and misoprostol. Zhonghua $\mathrm{Fu}$ Chan Ke Za Zhi 1996;31:681-4.

6. Li XM, Wan J, Xu CF, Zhang Y, Fang L, Shi ZJ, Li K. Misoprostol in labour induction of term pregnancy: a meta-analysis. Chin Med J (Engl) 2004;117:449-52.

7. Kelly AJ, Kavanagh J, Thomas J. Relaxin for cervical ripening and induction of labour. Cochrane Database Syst Rev 2001;(2):CD003103.

8. Heikinheimo O. Clinical pharmacokinetics of mifepristone. Clin Pharmacokinet 1997;33:7-17.

9. Hapangama D, Neilson JP. Mifepristone for induction of labour. Cochrane Database Syst Rev 2009;(3): CD002865. doi: 10.1002/14651858.CD002865.pub2.

DOI: $10.5455 / 2320-1770$. ijrcog20130206

Cite this article as: Athawale R, Acharya N, Samal S, Hariharan C. Effect of mifepristone in cervical ripening for induction of labour. Int $\mathrm{J}$ Reprod Contracept Obstet Gynecol 2013;2:35-8. 